\title{
『一乗寺村文書』の普請願書にみる愛宕郡一乗寺村の民家型式 MINKA TYPE OF ATAGO COUNTY ICHIJOJI VILLAGE TO SEE THE BUILDING PERMIT APPLICATIONS "ICHIJOJI VILLAGE DOCUMENTS"
}

丸 山俊 明*

Toshiaki MARUYAMA

This paper reports the results of examination 7 building permit application form in the late Edo period, farmer of Atago county Ichijoji village, submitted to Machibugyo office.

Ichijoji village, is the distribution areas of Kitafunai type houses. Also the plane that was written to the building permit application, the placement of the room with Kitafunai type can be observed.

However, Iwakura type is also mixed. In addition, roof model that has a gable to the long side of the building was also present.

Keywords : house style, Miyako meisho zue, Ichijoji village, Building permit application forme 民家型式，都名所図会，一乗寺村，普請願書

\section{1. はじめに}

京都府の民家は、京都府教育委員会が昭和 39 年度から 6 次にわた り実施した緊急調查の成果が『京都府の民家調査報告』第 $1 \sim 7$ 冊 にまとめられている。そして第 7 冊第 2 章の「京都府民家の総観」 では、永井規男が「限定された小地域においていくつかの民家平面 を採集して検討してみると、まず例外なしにそれらは同一原理をも って平面を構成している（略）これと同じ平面の構成原理をもつ民 家が、地域的に連続して存在し、一定範囲の領域分布を示すとき、 これを一つの民家の型として設定する」と述べた ${ }^{2}$.1。ここで平面を 注視する理由は、「民家は平面（間取り）や構造、材料、工法が空間 を構成する。この空間を分類するには、平面が最もあつかいやすい。 なぜなら、限られた地域の民家を調査すると、同じ構成の平面が多 い。それは農村なら農業、山村なら林業というように、地域共通の 生業に適応して生み出された平面である。だから、同じ平面の分布 地域を明らかにして、分布地域全体の略称を付けて設定するのが民 家型式」と説明している注2。帛して北から順に「丹後型（広間型）」 「北山型」「北船井型」「攝丹型」「南山城型」「町家」を設定した。 さらに永井は、昭和 52 年の摂丹型に関わる論考 3 で、京都盆地 北隣の岩倉盆地の旧愛宕郡岩倉村における古民家すべてを「岩倉型」 とした。その上で、摂丹型分布域における岩倉型の散在も指摘し、 かつては広く分布していたが摂丹型に虫食された古型式とした。

以上、京都府下に 7 つの民家型式が設定された(図 1)。この様な 設定や定義に対し、明確な反証や批判的見解は示されてこなかった。

\section{丹後型 (広間型) 分布地域}

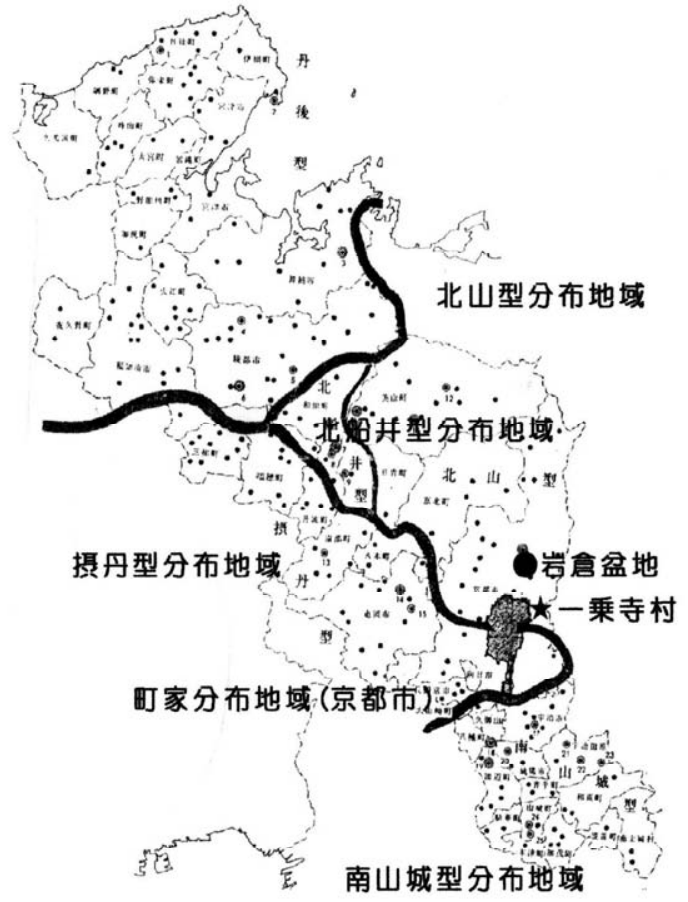

図 1 民家型式の分布（『京都府の民家調查報告』第 7 冊転載） 
これに対して著者は、京都市歴史資料館架蔵フィルムの『岩倉村 文書』より、京都代官所宛の普請願書を検討した洋4。そして、岩倉 型だけとされた岩倉盆地に北山型の存在を指摘し、遺構（金田家住 宅）も確認した。また、18 世紀後半の普請願書では土間に床几がな いのに、19 世紀には現れている事を取り上げて（写真 1)、下手表に あった居間・食事機能が床几周辺へ移った結果、床上 4 室は下手表 に日常接客用の「おうえ」、下手奥に寝室の閉鎖的「なんど」、上手 列に続き座敷の構成になったという岩倉型の変化を指摘した (図 2)。

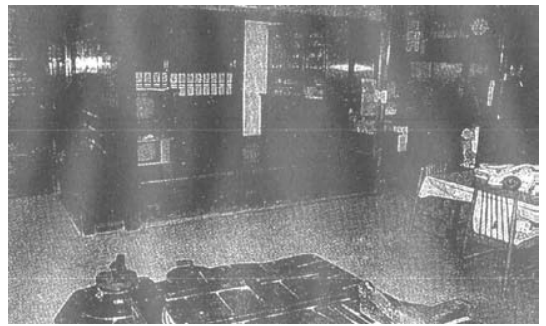

写真 1 岩倉型の土間の床几（奥）周辺の居間・食事機能

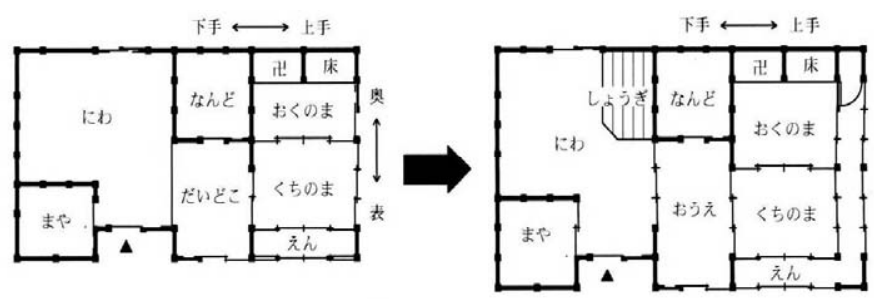

図 2 岩倉型の変化（『京都府の民家調査』と普請願書から作図）

現在の岩倉盆地では、遺構は二階建てに改変され、物置や階段室 にされたナンドは閉鎖性を失った。しかし普請願書では江戸時代を 通じて菜莫入母屋が確認され、昭和 40 年代の「くずやおろし」で 2 階建てに改変したとのヒアリング結果と整合した (写真 2、写真 3 )。

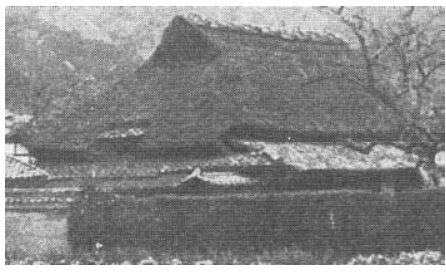

写真 2 葍莫入母屋の岩倉型

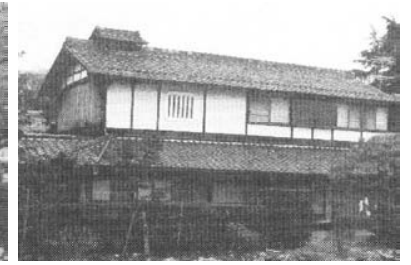

写真 3 くずやおろし後
この様に普請願書には、昭和の遺構調査で補足出来なかった型式 や変化を見出す可能性がある。もっともまとまった普請願書の採集 は容易ではないが、今回、京都市歴史資料館架蔵フィルムの『一乗 寺村文書』 に幕末の 7 点を見出した。本論はこれらに平面や屋 根形式を読み取り、北山型分布地域内とされてきた同村（図 1）に 北船井型が存在した可能性を指摘する。また長辺方向から妻入とい う、京都府下の民家調查では未報告の屋根形式にも言及する。

\section{2. 江戸時代の一乗寺村と普請願書の書式および史料批判}

旧愛宕郡一乗寺村は現在の一乗寺、北山型分布地域の南端とされ た地域にあたる（図 1)。江戸時代は菜種栽培が盛んな京都近郊農村 で、元禄 2 年 (1689)『京羽二重織留』に「家数八十二軒、外に六軒

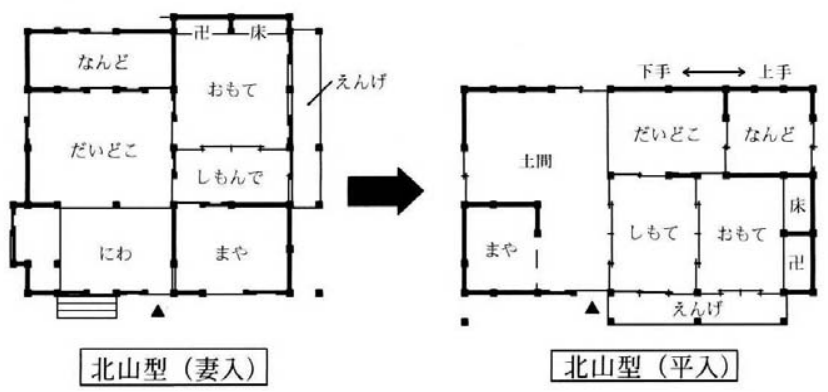

図 3 北山型の変化（『京都府の民家調查』を参照して作図）
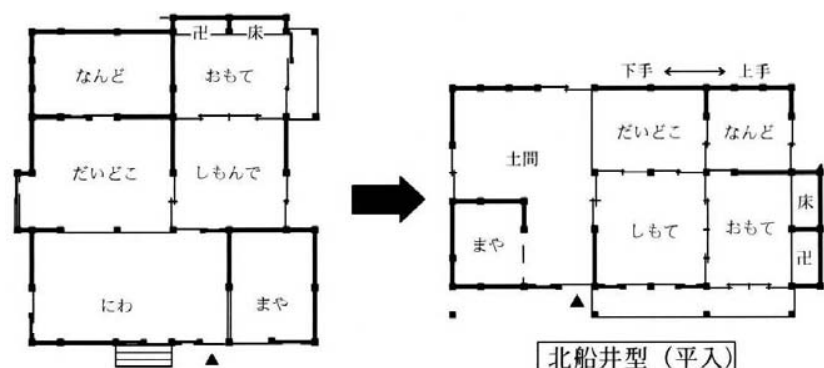

北船井型 (平入)

北船井型 (妻入)

図 4 北船井型の変化（『京都府の民家調査』を参照して作図）

寺、石高千八百二十石二斗四升九合」 ${ }^{11.6}$ 、享保元年 (1716) の『山 城国高八郡村名帳』には村高 1864 石余とある。そこに霊元法皇料 28 石余や曼殊院宮領 306 石など合計 31 の領主がいる相給農村で 7 、 近代の『京都府地誌』洋8 では 171 戸に 1015 人が記録されている。

この様な一乗寺村に言及した民家研究は管見に入らないが、北隣 の修学院村では津田良樹が文政 7 年（1824）の光格院宮の修学院行 幸時の宿となった百姓家 10 戸すべてを整形四間取りと報告した ${ }^{2}$ 。 一乗寺村が分布地域とされる北山型は縦喰い違いが特徴とされ、京 都府下の整形四間取りは北船井型と南山城型に指摘される

このうち北船井型は分布地域が北山型と隣接し（図 1)、共に妻入で あったのが 19 世紀に平入化したとされる（図 3、図 4)。平入化した 床上構成は表列に続き座敷、奥列の下手奥が居間・食事機能のダイ ドコ、上手奥が寝室のナンドで共通するが、北山型は縦喰い違いで 北船井型は整形が特徵とされる。この違いに永井規男は、山間部の 北山型より早く農業集落化した地域の型式が北船井型と述べた

以上をふまえた上で、まず一乗寺村普請願書の書式を確認する。 一冊の帳面に閉じられた 7 点は全て表書と指図、願文からなり、表 書は年記と「村控」「普請御願」「城州愛宕郡一乗寺村」すなわち山 城国愛宕郡一乗寺村の「百姓某」と申請人の名前が記される。年記 は寸べて安政 3 年（1856）なので、同年に一乗寺村百姓が提出した 普請願書の村控えを、村役人が閉じたものと推測される。

指図には、屋敷内の配置と居宅の間取り、床の間・仏壇の位置、 大戸口の位置が読み取れる。屋根の棟の流れ方向や、棟位置も大凡 推測できるものがある ${ }^{*} 12$ 。例えば 8 月 10 日付の喜兵衛の場合（図 5)、敷地は北に隣人が住み、他三方が「畑」である。大戸口は南側 にあり、棟に対し直角に入る平入である。西側「物入」の利用形態 は不明だが、平面は基本的に田の字の整形四間取りとみなせる。そ して「床」「佛間」がある上手表の 6 帖と延長線上の下手表 6 帖の表 列に続き座敷が推測され、上手奥の「ヨシ入」付き 4 帖半に寝室の 


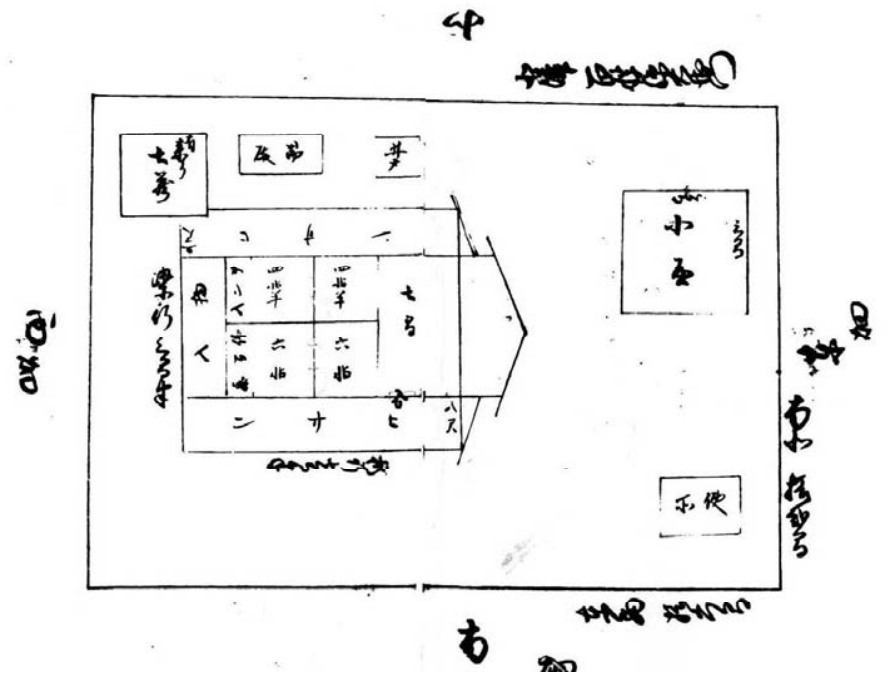

図 5 喜兵衛普請願書の指図

ナンド、さらに下手奥の 4 帖半に居間・食事機能を見れば、室配置 は平入化した北船井型と近似する。また南北両方の庇が目を引くが、 例えば岩倉型遺構にも多くあって、珍しいものではない（写真 4)。

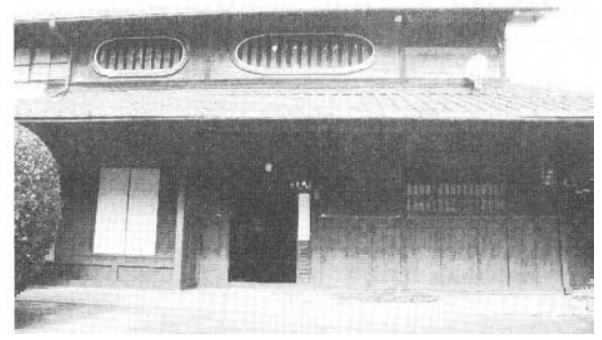

写真 4 岩倉型遺構の庇（京都市左京区岩倉）

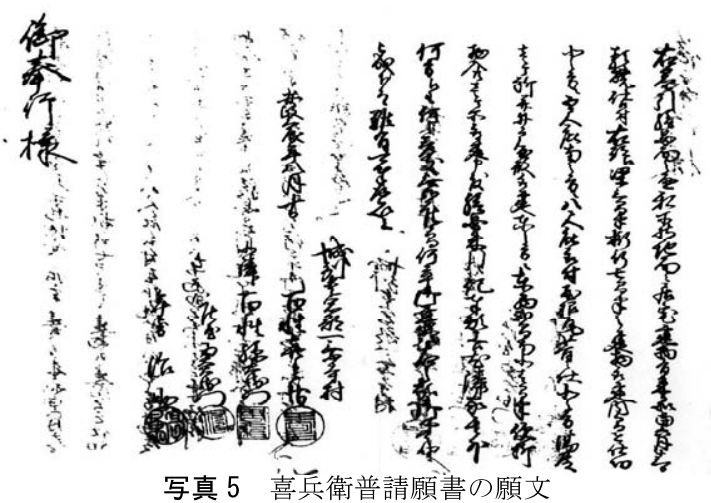

指図に続き願文が記され（写真 5)、以下の様に読み下せる。

右墨引絵図面之通、私所持地面居宅建物有来り候処、当六月十 三日類焼仕候付、右跡梁三間半・桁行七間半之建物取建、内間 ～仕切、北ノ方二五尺庇、南之方二八尺庇取付、屋根瓦莫二仕、 北之方二湯殿壱箇所并井戸屋形取建、東之方二東西二間半・南 北壱間半之便所 - 物入共壱箇所取建申度、絵図朱引記奉願候、 尤隣家其外何方江も何ノ差支無御座候間、何卒御慈悲二右之趣 御聞届被成下候ハバ難有可奉存候、以上

$$
\text { 城州愛宕郡一乗寺村 }
$$

安政三辰年八月十日 百姓 喜兵衛 印
北隣 百姓 孫左衛門 印

庄屋奥右衛門 印

御奉行様年寄治助印

敷地は類焼した居宅と同じ場所で、建築要因は 6 月 13 日の火事の 延焼被害である。前者は農地でない事、後者はやむをえない事情で ある事を説明しており、それにより許可を願う文章となっている。

建築規模は梁行方向 3 間半・桁行方向 7 間半とあり、指図より上 屋梁長さと推測されるが、いわゆる梁間 3 間規制をこえる理由は明 らかでない。「内間を仕切り」は床上を 4 室に区切る意味で、北側に 長さ 5 尺、南側に長さ 8 尺庇を付ける。これら庇も、そして大屋根 も瓦莫であるが、大正期に撮影された「一乗寺門口町山本久四郎私 宅」が瓦莫で切妻なので(写真 6)、指図の主屋も切妻と推測される。 このほか外風呂（「湯殿」）や便所、井戸屋形の建築も記している。

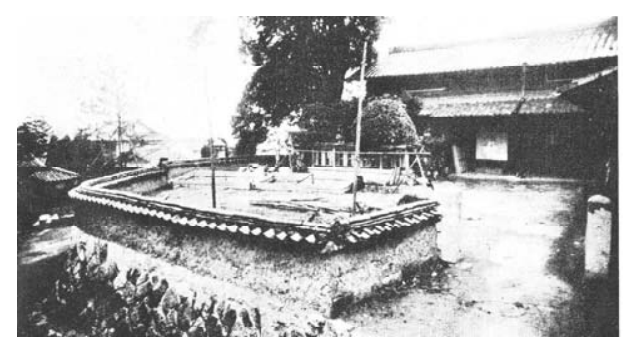

写真 6 旧愛宕郡一乗寺村の百姓家

さらに願文の末尾では、近隣へ迷惑をかけない旨を誓約する。こ の誓約も 7 点に共通するが、徳川政権が奢侈禁令・年貢増徴で財政 再建を進めた江戸時代前期の京都町奉行所宛の普請願書では、「普請 成就、早速御訴申上候間、御見分之上、指図之表相違之義或者増作 等仕候ハバ造作御潰被成、其上如何様之曲事二も仰付可被成候」等 と、竣工届の提出を誓約し、竣工検査の実施を求め、申請図との相 違や増築は取り潰しの受忍まで記していた。これらが一乗寺村普請 願書に見当たらない理由は、以下二つの町奉行所の触書に窺える。

・明和 8 年 (1771) 9 月の触書 14$)$

…洛外町家・在家普請之義 (略) 新規二建家地相願候者勿論、 新規建家併建継致候分者（略）可願出候、家作之有分者修復 併内住居等之造作之義は以来願出二不及候

·安永 3 年 (1774) 5 月の触書 ${ }^{+15)}$

…寺社境内 - 年貢地等之内、新規建家願所者格別、其余之百 姓家・町家共有来地面之普請之儀者向後出来見分不差遣候 町奉行所は、元から百姓家があった場所の建築行為には、竣工検 查役人を派遣しないと触れたのである。願文冒頭で元から百姓家が あった場所を明らかにする事(「私所持地面居宅建物有来候処」)や、 末尾書式が江戸時代前期と違うのも、この触書の結果と考えられる。 なお一乗寺村は、明和 4 年（1767）12 月の触書で町奉行所への建 築許可申請を義務付けられている ${ }^{2} 16$ 。このため文中の「御奉行様」 は町奉行であり、7 点は幕末の町奉行所宛普請願書と判断出来る。

\section{3. 喜兵衛以外の普請願書にみる民家型式}

\subsection{8 月付、平右衛門の普請願書}

願文には「私所持地面居宅建物有来候処、当六月一三日類焼仕候 二付、右跡江梁三間半・桁行六間之建物取建、内間を仕切、本間之 


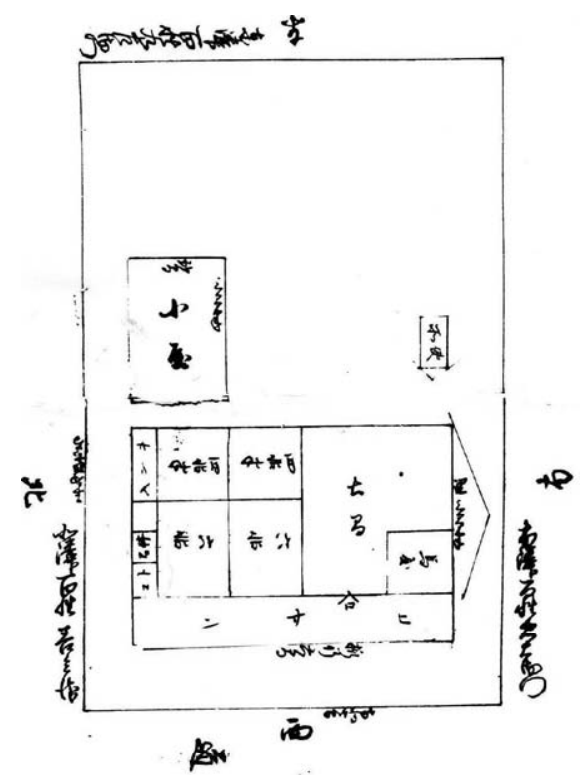

図 6 平右衛門普請願書の指図

庇取付、北東之方二東西三間半 ・南北二間之塗屋取建、同前之方二 便所取建、何茂菜葺二仕申度、絵図朱引二記奉願奉候」とあり、喜 兵衛同様に延焼が建築要因であるが、願文より㩰葺で、喜兵衛の瓦 苟とは異なる。指図では切妻か入母屋か判断できないが（図 6)、76 年遡る安永 9 年 (1780) 初版の『都名所図会』注17 より「一乗寺村・ 北山御坊・詩仙堂・八大天王」図では（図 7)、「さがり松」から伸 びる曼殊院道沿い（現在の一乗寺釈迦堂町辺り）に草莫が並ぶ。切 妻はなく入母屋で揃っており、この指図にも可能性がある。

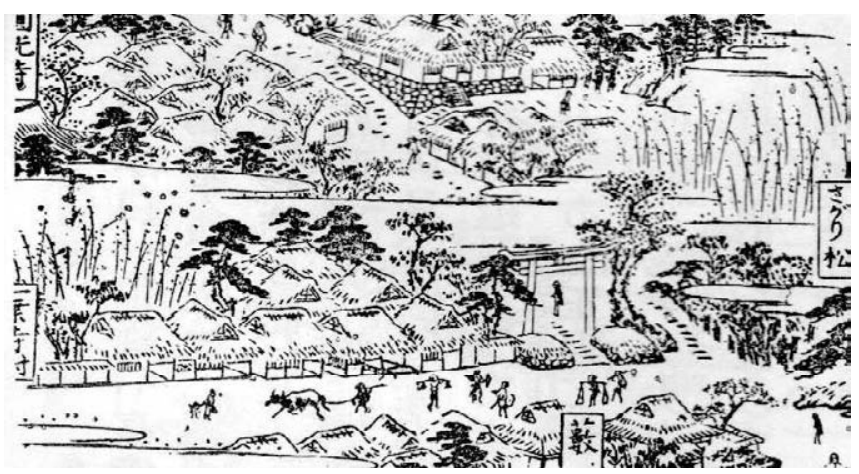

図 7 「一乗寺村・北山御坊・詩仙堂・八大天王」図、部分

内厩を持つ点も喜兵衛の指図と異なるが、「トコ」「佛間」のある 上手表と延長線上の下手表に続き座敷をみると、上手奥は居間・食 事機能、下手奥は寝室と判断される。つまり喜兵衛同様に整形四間 取り、平入化した北船井型の室配置である。なお一般的に百姓家は 大戸口の前を広くとるが、背面を広くする理由は明らかでない。

\subsection{9 月 22 日付、仁兵衛の普請願書}

この指図には帖数や床、仏壇の記入がない（図 8)。願文に「私所 持地面居宅建物有来候処、同表之方、庇破損二付修復仕、同東南之 方二東西二間 - 南北三間半之土蔵一䇢所取建、同南続二便所取付、 何茂瓦莫二仕申度」とある様に、庇の修復と土蔵や便所の建築を願 うためと思われる。それらの屋根は全て瓦莫で、享保 5 年（1720）4 月の瓦莫規制の解除 18 から約 140 年を経た後の普及状況が窅える。

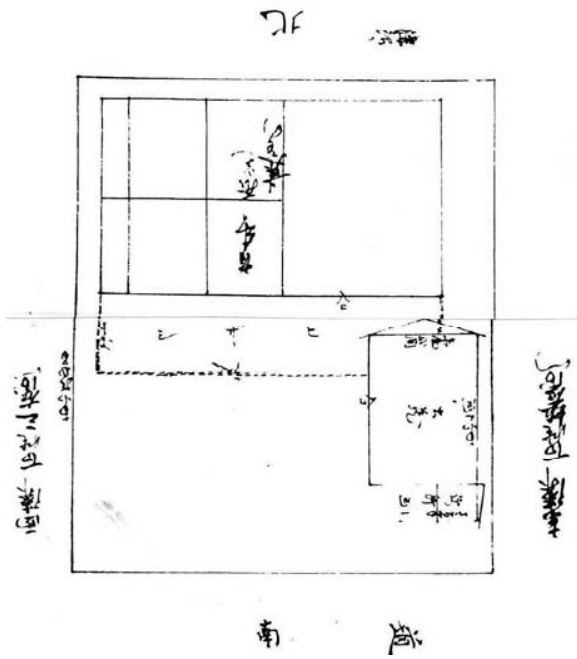

図 8 仁兵衛普請願書の指図

大戸口は長辺方向にあって平入と想像されるが、屋根の流れ方向 が記されず確定出来ない。平面は整形四間取りだが、室機能は不明 である。ただ上手列の妻側に床や仏壇、押入を想像させる線があり、 「同じ平面の構成原理をもつ民家が、地域的に連続して存在」（第 1 節)する事からすると、表列に続き座敷を置く北船井型と近似する。

\subsection{9 月 22 日付、清次郎の普請願書}

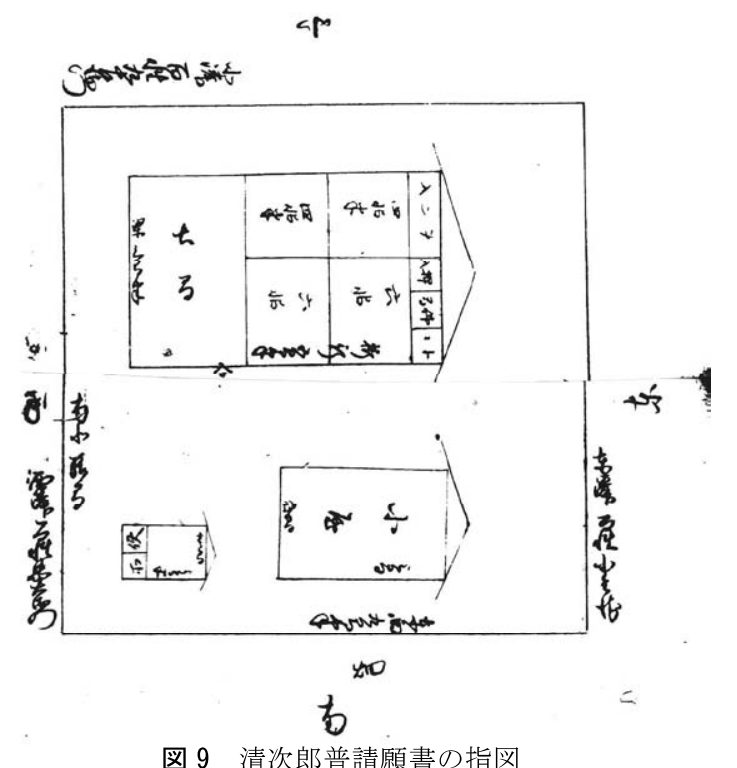

願文に「私所持地面の居宅建物有来候処、当六月一三日類焼仕候 二付、右跡江梁三間 - 析行五間半之建物取建、内間仕切、東西三間 南北二間之小屋取建、同南西之方二便所取建、何茂屋根蒠莫二仕度、 絵図朱引二記奉願候」とあり、喜兵衛や平右衛門と同じ延焼からの 建て直しと判断される。指図では屋根の流れ方向から平入と思われ (図 9)、平面は整形四間取り、上手表が「トコ」「佛間」「押入」を 持つので、延長線上の下手表と続き座敷を構成するのであろう。「ヨ シ入」を持つ上手奥に寝室機能のナンド、残る下手奥に居間・食事 機能を見ると、やはり平入化した北船井型と同じ室配置となる。

\subsection{2 月 16 日付、忠左衛門の普請願書}

願文に「私所持地面居宅有来候処、破損二付取払、右跡江梁五間 


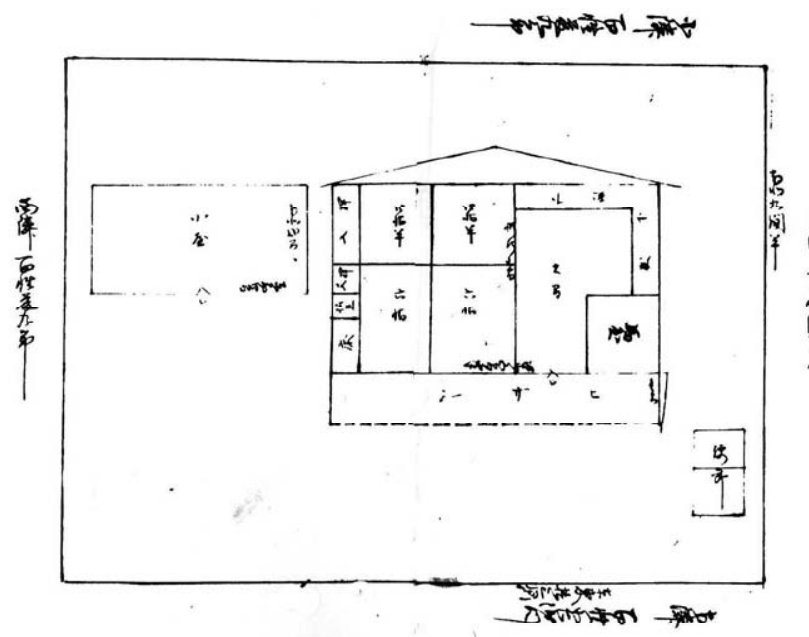

図 10 忠左衛門普請願書の指図

半・桁行三間建物取建、内間 7 仕切、屋根葍莫二仕、南之方二一間 通庇取付、北東折廻下屋 7 付、庇廻者瓦申、南之方東西四間 - 南北 二間之小屋一箇所、東南之方二便所一箇所、何茂瓦莫二仕申度 (略)」 とあり、「破損」からの建て直しで、庇は瓦莫、屋根は葍荣と分る。

平面はやはり整形四間取りで（図 10）、上手表に「床」「仏旦」「押 入」があるので、表列の 6 帖二間が続き座敷、奥列に居間・食事機 能と寝室が推測される。つまり北船井型と同じ室配置である。

そして、屋根の流れ方向が大戸口に対し左右に分かれる点が注目 され、これだと長辺方向からの妻入となる。京都府下の妻入は摂丹 型と平入化前の北山型、北船井型に報告されるが、確認出来る遺構 は全て短辺方向から妻入であり（写真 7 が北山型古遺構で、写真 8 が摂丹型古遺構）、長辺方向からの妻入は見当たらない。

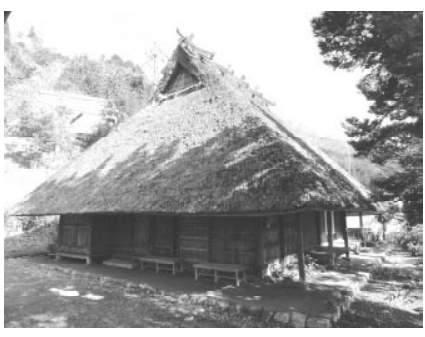

写真 7 石田家住宅 19

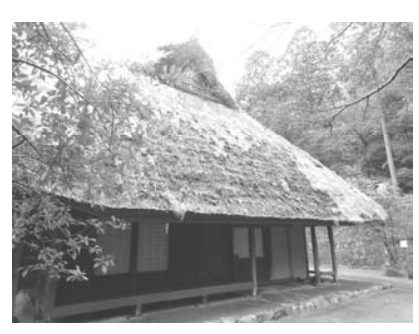

写真 8 旧岡花家住宅 $\$ 20$

\subsection{2 月 6 日付、甚兵衛の普請願書}

願文に「私所持地面居宅建物有来候処、破損二付取払、右跡畑地 致置候処、元建家地面二相違無御座候二付、今度梁五間半・桁行三 間建物相建、内間 $\exists$ 仕切、屋根葍莫二仕、西南折迴間半庇取付、北 之方二間半之下屋 $ᄏ$ 付、庇廻者瓦申、東南之方二東西三間半 - 南北 二間之小屋一箇所、北之方二便所一箇所何茂取建、屋根囟莫二仕度」 とあり、破損」した主屋を解体、それから相当期間が経過してから、 元あった場所に建て直しをしたいと申請寸る内容である。

指図より忠左衛門同様に長辺方向から妻入と思われ（図 11）、願 文に大屋根は菜莫、庇は瓦莫と記す点も同じである。しかし平面は 異なる。床・佛壇が上手奥にあり、延長線上の上手表と続き座敷を 構成すると思しい。そうすると「押入」が付く下手奥 3 帖が寝室、 残る下手表の 4 帖半が居間・食事機能とみるのが妥当であろう。寝

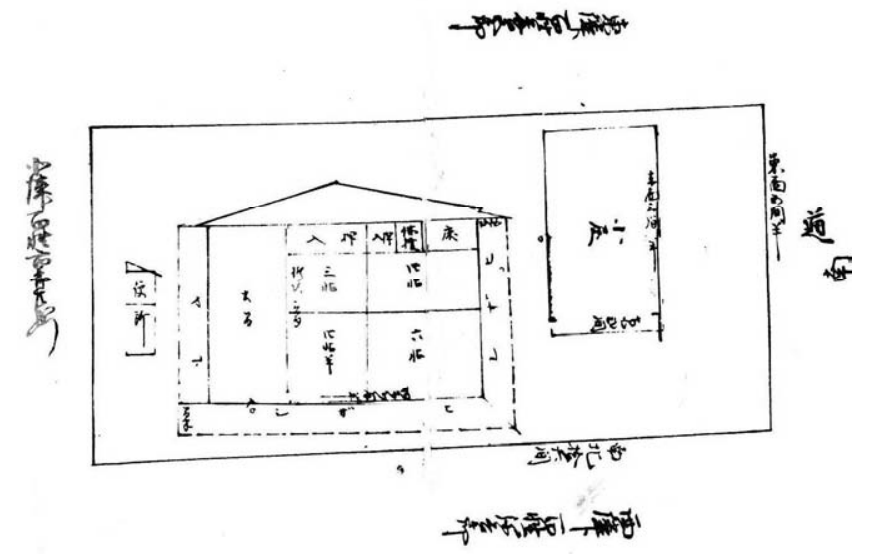

図 11 甚兵衛普請願書の指図

室の閉鎖性は確認出来ないが、この室配置は 18 世紀までの岩倉型と 一致する (図 2 左)。つまり平面による民家型式は岩倉型と近似する。

\section{6 月日記入なし、佐五左衛門の普請願書}

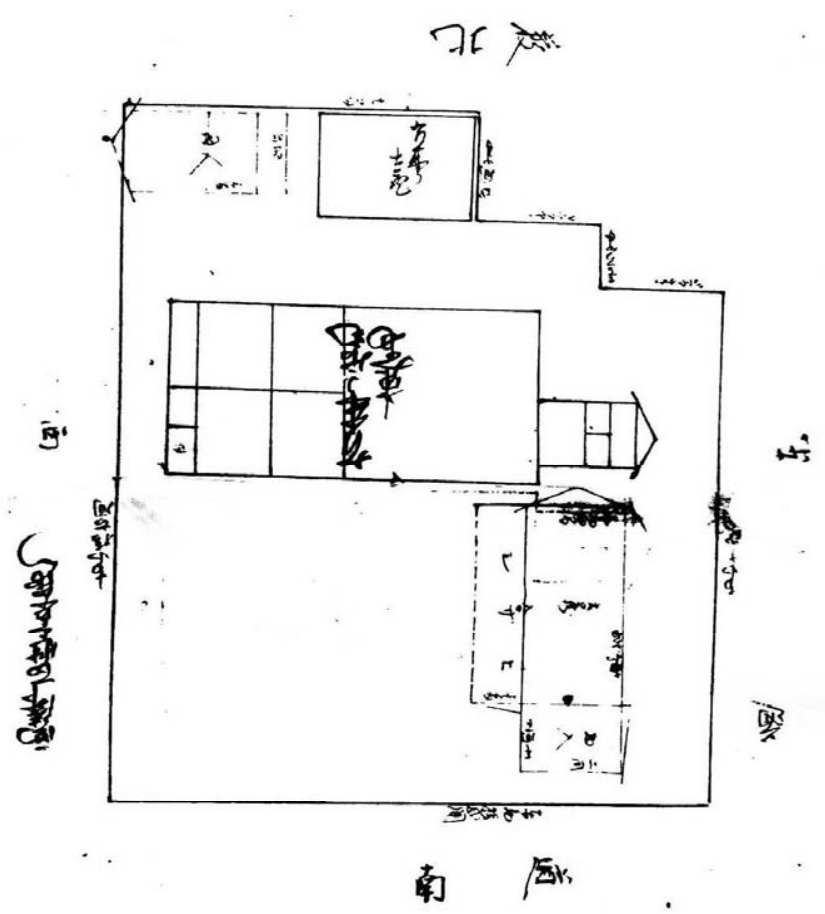

図 12 佐五左衛門普請願書の指図

この指図にも帖数や屋根の流れ方向がない（図 12）。願文に「私 所持地面居宅建物有来候処、同東南之方二東西二間半 - 南北三間之 土蔵一箇所取建、壱間通庇付、南続二㚃間半 - 武間之物入取付、北 東之方東西三間・南北二間之物入取建、何茂瓦莫二仕申度」とあり、 「物入」がある庇付き「土蔵」申請のためと判断される。それでも 主屋の平面は整形四間取りと分り、大戸口は南側にある。さらに「床」 らしい文字や仏壇か押入らしい空閒が上手表にあり、上手奥にも押 入らしい線があるので、表列に続き座敷を置く北船井型と近似する。

\section{4. 一乗寺村普請願書から得られる知見}

幕末の一乗寺村普請願書 7 点は整形四間取りが共通し、うち 6 点に平入化した北船井型と近似した室配置を確認した。一定範囲に 


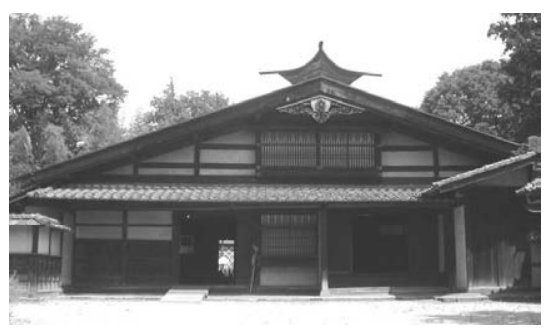

写真 9 馬場家住宅 $\$ 21$

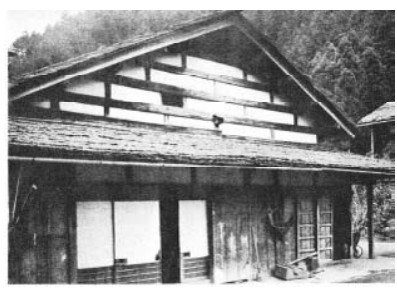

写真 10 背戸家住宅 $\$ 22$

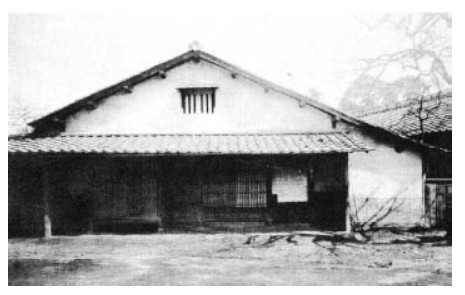

写真 11 山本家住宅 $\$ 23$
「同じ構成原理」（第 1 節）の平面を確認出来た事になる。それが 民家分布地域図で示された北山型でなく北船井型に近い点について、 永井規男が山間部の北山型より早く農業集落化した地域の民家型式 が北船井型とした事（第 2 節）をふまえれば、北船井型分布地域が 北山型分布地域西端にある様に、南端の一乗寺村でも同じ要因で整 形化した可能性が浮かぶ。農業集落化と整形化の因果関係は未解明 であるが、隣の修学院村にも整形が指摘された事も参考になる。

また、1 点の岩倉型も無視出来ない。これは岩倉型のみとされた 岩倉盆地に少数の北山型を確認した状況と同じであり、岩倉盆地と 一乗寺村という 2 箇所で民家型式の混在を確認した事になる。理由 を明らかにする史料は得られず、移築や転居等様々に想像されるが、 いずれにしても一定地域に民家型式のヴァリエーションが存在した 事は確かであり、分布地図の線引きは総体的な傾向と判断される。

最後に長辺方向から妻入について、忠左衛門之甚兵衛の主屋は、 梁行五間半に䔔莫を架ける。『都名所図会』にみた一乗寺村の草莫は 入母屋であるが (図 7)、短辺の短さから考え難い。そこで長辺方向 に妻壁を見せる姿を探すと、長野県松本市一帯の本棟造り が 24 周 知であるが (写真 9)、京都近郊農村でも大正期に撮影されている。

愛宕郡花背村大布施の背戸家住宅（写真 10）は山間部の北山型分 布域のもので、平面規模には説明がないが、写真を見る限り板莫か 杉皮莫の様で、長辺方向から妻入で切妻と思しい。次に乙訓郡久世 村の山本家住宅（写真 11）は「間口四間奥行三間半の家に西側に一 間の下屋が附いてみる」と説明され、長辺からの妻入が明確である。 草莫でなく「妻入の瓦葺切妻」であるが、「農家には珍しい型」と記 される一方「同字には外にも一軒同型の家がある」とあって複数の 存在が分かる。これらの姿から忠左衛門主屋（図 10）も甚兵衛主屋

（図 11）も、瓦庇付きの菜莫切妻と想像される。ただし蒠草は勾配 が急になるので、梁間五間半に架けた場合の棟高は相当に高くなる。 構造的に不可能とまでは言えないが、少なくともその様な屋根形式 は京都府下の民家調査報告に見当たらない。平面に基づく民家型式 に関係のない屋根形式のヴァリエーションであり、存在の確定には さらなる史料の収集が必要であるものの、京都府下に指摘がなかっ た屋根形式が存在した可能性を見出した点は、新しい知見と言える。

\section{5. 本論のまとめ}

安政 3 年 (1856) に愛宕郡一乗寺村百姓が京都町奉行所へ提出し た普請願書 7 点を取り上げた本論の結果を、以下にまとめる。

- 一乗寺村は、民家分布地域図では北山型分布地域とされた中 にあるが、特徴とされる縦喰い違いは見当たらない。むしろ 平入化した北船井型と近似した整形四間取りを確認出来る。

- 北山型分布地域の西端が農業集落化して整形四間取りの北 船井型が現れたとする永井の見解を参考に寸ると、農業集落 化と整形化の因果関係は明らかでないものの、北山型分布地 域南端の一乗寺村にも同様の可能性が浮上寸る。

・岩倉型の指図が 1 点あり、民家型式のヴァリエーションが存 在した。岩倉盆地における北山型の混在状況と同じであり、 従来の民家分布地図の線引きは、総体的な傾向とみなせる。

・ 長辺方向から妻入の屋根形式がある。草莫で、短辺方向の短 さからして切妻と推測される。この様な屋根形式は、京都府 下の民家型式に報告例がなく、現在の一乗寺にも遺構はない。 今後の課題として、北山型分布地域の端部における農業集落化と 平面の整形化の類例收集ならびに因果関係の解明や、長辺方向から 妻入の䔔蕞切妻の形態の確認がある。さらなる史料収集を進めたい。

注

注1）京都府の民家, 調査報告, 第七冊, 昭和 48 年度京都府民家緊急調 查報告, 京都府教育委員会, 1975

注2）上掲書，第 2 節，永井規男：京都府民家の総観

注3）永井規男: 摂丹型民家の形成について, 日本建築学会論文報告集, 第 251 号, 1977. 01

注4）丸山俊明：『岩倉村文書』にみる岩倉型民家，岩倉型民家の研究， その 1 ，日本建築学会計画系論文集，第 551 号，2002.1 京都市歴史資料館架蔵, 紙焼き史料 新修京都叢書, 第二巻, 臨川書店, 1968 史料, 京都の歴史，8，左京区，京都市， 1985 京都府総合資料館所蔵, 行政文書, 所收 津田良樹 : 光格院修学院御幸史料からみた文政 7 年の修学院村・ 一乗寺村の民家について, 日本建築学会大会学術講演梗概集, 北 海道, 1986. 8

注10）上掲書，第 2 節，永井規男：京都府民家の総観 注11）上掲書，第 2 節，永井規男：京都府民家の総観 注12）本論では指図を、主屋の入口を下に来る形で揃えて掲載した。 注13）毎日新聞社編：京都民家譜, 日本資料刊行会, 1977 注14）京都町触集成，第 5 巻，pp. 253〜254，岩波書店，1984 注15）京都町触集成, 第 6 巻, pp. 453 454, 岩波書店, 1985 注16）丸山俊明 : 京都町奉行所の明和四年一二月の触書について, 江戸時 代の山城国農村部に㧈ける建築規制, その二, 日本建築学会計画系 論文集, 第 539 号, 2001.1。丸山俊明 : 山城国南部に打ける建築規 制の転換について，江戸時代の山城国農村部における建築規制，そ の一, 日本建築学会計画系論文集，第 535 号，2000.9。

注17）新修京都叢書, 第十一巻, 都名所図会, 光彩社, 1968 注18）丸山俊明：京都の町家と町なみ，第 2 章，昭和堂，2007 注19）南丹市美山町樫原大原谷にて著者撮影 注20）綾部市本宮町大本教本部にて著者撮影

注21）本棟造りの遺構（長野県松本市内田）。成立には破風の家格表現を 注視した上掲注 3) の永井論考をふまえた中尾七重の研究がある(中 尾七重 : 本棟造の分布と信濃国小笠原氏支配地域の関連について, 日本建築学会計画系論文集, 第 603 号, 2006)。しかし一乗寺村普 請願書には家格表現に踏み込むだけの材料がなく、遺構もない。

注22）毎日新聞社編：京都民家譜，日本資料刊行会，1977

注23）毎日新聞社編：京都民家譜, 日本資料刊行会, 1977 